\title{
Creating Histories: Different Perspectives, Controversial Narratives at Rákóczifalva, an Early Copper Age Site on the Great Hungarian Plain
}

\author{
Zsuzsanna Siklósi $^{1 *}$ (D), Norbert Faragó ${ }^{1}$ (D) , János Dani ${ }^{2}$ (D),

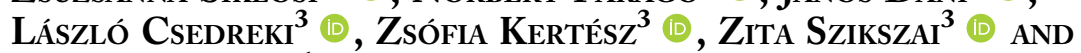 \\ Márton SZILÁGYI ${ }^{1}$ \\ ${ }^{1}$ Institute of Archaeological Sciences, Eötvös Loránd University, Budapest, Hungary \\ ${ }^{2}$ Déri Museum, Debrecen, Hungary \\ ${ }^{3}$ Institute for Nuclear Research (ATOMKI), Debrecen, Hungary \\ *Corresponding author: email: siklosi.zsuzsanna@btk.elte.hu
}

A Copper Age settlement and cemetery was fully excavated at Rákóczifalva-Bivaly-tó Site 1/C in 2005-2007, making it possible to compare the use of its material culture in closely related, coeval, but different archaeological contexts. Such a rare set of circumstances allows the authors to highlight methodological issues associated with the distorting effect of archaeological finds made on sites where only settlement or burial data are available, and on the importance of choosing appropriate analytical units.

Keywords: Early Copper Age, Great Hungarian Plain, cemetery, settlement, site-based approach

\section{INTRODUCTION}

By the end of the twentieth century, after a century of archaeological research, a widely accepted chronological framework had been developed for the Copper Age in eastern Hungary. After the end of the Late Neolithic tells, the Early Copper Age on the Great Hungarian Plain was represented by the Tiszapolgár culture between 4500 and $4000 \mathrm{cal}$ BC. This was followed by the Middle Copper Age Bodrogkeresztúr culture between 4000 and 3700 cal вC (Kalicz, 1988; Yerkes et al., 2009). Although the Bodrogkeresztúr culture was assumed to have developed from the Tiszapolgár culture, changes in pottery style and the more frequent appearance of copper and gold items clearly separates the two cultures (BognárKutzián, 1963, 1972; Patay, 1974).

Cemeteries provided the bulk of information on the Early and Middle Copper Age. Given that settlements were hardly known (Bognár-Kutzián, 1972; Patay, 1974), the Copper Age societies represented by the burial sites were considered to be mobile pastoral communities (Sherratt, 1984; Bökönyi, 1988). However, recent Strontium (Sr) isotope analyses have greatly modified this view (Giblin et al., 2013). Diet did not change at the

(c) The Author(s), 2022. Published by Cambridge University Press on behalf of the European Association of Archaeologists. This is an Open Access article, distributed under the terms of the Creative Commons AttributionNonCommercial-NoDerivatives licence (https://creativecommons.org/licenses/by-nc-nd/4.0/), which permits non-commercial re-use, distribution, and reproduction in any medium, provided the original work is unaltered and is properly cited. The written permission of Cambridge University Press must be obtained for commercial re-use or in order to create a derivative work. doi:10.1017/eaa.2022.2

Manuscript received 15 February 2021,

accepted 18 January 2022, revised 17 July 2021 
beginning of the Copper Age, and the consumption of dairy products did not increase significantly (Hoekman-Sites \& Giblin, 2012; Giblin \& Yerkes, 2016). At the beginning of the Copper Age, the settlement pattern had nevertheless been transformed: it now consisted of small, independent hamlets of brief duration (Parkinson, 2006). For the first time in the history of the region, formal cemeteries emerged, after 4400 cal BC (Raczky \& Siklósi, 2013; Siklósi \& Szilágyi, 2021). The find material called Tiszapolgár culture came into existence: the pottery style became homogeneous and, in addition to copper ornaments, heavy copper tools and gold ornaments appeared (Bognár-Kutzián, 1963, 1972). Yet several elements of the Late Neolithic material culture and mortuary practices were maintained, such as settlement burials (Raczky et al., 2014). Thus, the changes that came about with the advent of the Tiszapolgár culture have been interpreted as complex, internal sociocultural transformations (Parkinson, 2006).

The Bodrogkeresztúr culture was defined by certain elements of its material culture (pottery types such as the so-called milk jug, two-handled cups, and largehandled jugs; specific vessel decorations such as net patterns or meander motifs; appearance of copper axe-adzes and flat axes; gold ornaments found in formal cemeteries) and a higher proportion of metals (Patay, 1974). Burial rites were determined by the age, gender, and rank of the individuals (Bognár-Kutzián, 1963; Sofaer Derevenski, 1997; Lichter, 2001). While the distribution of finds of the Tiszapolgár culture was limited to the Great Hungarian Plain, those of the Bodrogkeresztúr culture spread further afield, including the Danube-Tisza interfluve area and Transylvania (Kalicz, 1988; Luca, 1999). However, in many cases pottery could not be attributed to one or the other culture based on its style, making it difficult to distinguish between the two (Bognár-Kutzián, 1963; Patay, 2008).

Although the number of Tiszapolgár settlements has significantly increased due to the intensification of settlement archaeology in the last twenty years, Bodrogkeresztúr settlements are still rare and their characteristics barely known (Kalicz, 1988; Patay, 2002; Parkinson, 2006; Gyucha, 2015; Szilágyi, 2015). Thus, the typo-chronology of the period is based on pottery recovered from burials and little is known about the possible differences in the use of the material culture between settlements and cemeteries.

In the 2000s, AMS radiocarbon measurements of the Rákóczifalva-Bivaly-tó Site 1/C cemetery led us to reconsider the chronology of the Early and Middle Copper Age on the Great Hungarian Plain. Rákóczifalva-Bivaly-tó Site $1 / \mathrm{C}$ was dated to the second half of the fifth millennium cal BC. It is the first Bodrogkeresztúrstyle assemblage to be dated to such an early time, which is partially coeval with Tiszapolgár assemblages (Kovács \& Váczi, 2007; Csányi et al., 2010). After further AMS measurements, we established a model which did not exclude a priori the contemporaneity of these cultures or pottery styles (Raczky \& Siklósi, 2013). This required not only a revision of the chronology, but also a new methodological and theoretical approach to understanding the period.

Archaeological cultures as analytical units cannot offer a satisfactory explanation for different assemblages found within cemeteries and settlements. In the absence of precise radiocarbon series, these dissimilarities used to be attributed exclusively to chronological differences. The newest AMS sequences have proven that both Tiszapolgár- and Bodrogkeresztúrstyle assemblages co-existed on the Great 
Hungarian Plain (Siklósi \& Szilágyi, 2021). In this article, we discuss this particular situation by presenting RákóczifalvaBivaly-tó Site $1 / \mathrm{C}$, where different pottery styles and a varied material culture were used at the same time in different contexts.

\section{A Multiscalar Approach and Site-Based Model}

Studies in prehistory in the twentieth century often used the concept of an 'archaeological culture' as a classificatory and analytical unit (Shennan, 1989; GravesBrown et al., 1996; Siklósi, 2006; Roberts \& Vander Linden, 2011). Although critical comment against the use of this notion is becoming more common, it is still widely used at the beginning of the twenty-first century as an analytical unit of social analysis at a macro level. The increasing application of aDNA studies has made this situation worse because archaeogeneticists have tended to uncritically apply their results to entire archaeological cultures (Furholt, 2019: 115). Indeed, the contradiction and weaknesses of using archaeological cultures as an analytical unit were pointed out in several cases, for example in the LBK, Baden, or Corded Ware complexes (Furholt, 2008, 2019; Hofmann, 2015, 2019; Frieman \& Hofmann, 2019).

The latter studies have repeatedly called attention to the phenomenon that overgeneralizations in macro-level analyses obscure diversity at lower levels. The strength of the 'third science revolution' in archaeology, defined by Kristiansen (2014) as characterized by the use of Big Data, new quantitative modelling, aDNA and strontium isotope analyses, and related scientific methods, however, lies precisely in the detection of these variabilities. The future of prehistoric studies is, in our view, the multiscalar modelling, which is built up from the local level, and which creates a conceptual framework and methodology for exploring the diversity of former communities by approaching them from the local level and then integrating them into the micro-regional and then into the regional level. At the same time, we need to reveal integrative processes in society that result in similarities at a higher level.

The multiscalar approach as a method in archaeology was inspired by the French Annales school and mainly by the work of Braudel (Braudel, 1967; Bintliff, 1991). The so-called 'time perspectivism' that emerges from the study of archaeological data constitutes another interpretative approach (Bailey, 2007). The multiscalar approach in turn did not escape criticism, not only for not sufficiently elaborating its theoretical foundations, but also because it was difficult to put into practice (Robb \& Pauketat, 2013). For the Copper Age in the Carpathian Basin, Parkinson and Gyucha (2007) applied the multiscalar approach, linking social processes to specific levels while still using the generalizations that characterize macro-level approaches (Gyucha et al., 2009; Yerkes et al., 2009; Parkinson et al., 2021).

Given this situation, we initiated a research project that included twentyseven new AMS measurements from several types of sites (settlements, cemeteries, and a single grave) in the Middle and Upper Tisza Region. These were supplemented with earlier AMS measurements from Early and Middle Copper Age sites on the Great Hungarian Plain, which were evaluated by Bayesian modelling (Siklósi \& Szilágyi, 2021). Our site-based, multiscalar approach allowed us to examine the differences and similarities in pottery styles, the formation of formal cemeteries, the appearance of metal objects, and the transformation of the settlement pattern between the Upper and the Middle Tisza region. Thus, the question of whether the emergence of certain 
elements of the material culture can be related to a type of site (formal cemetery or settlement) could be addressed, and its chronological position could be interpreted more precisely (Siklósi \& Szilágyi, 2016, 2021). First, our approach made it possible to avoid the pitfalls inherent in a macrolevel approach, which regards archaeological cultures as homogeneous analytical units and hence masks local or microregional diversity. Second, the more precise description and interpretation of the chronology of the finds allowed us to investigate the relationship between the Tiszapolgár and Bodrogkeresztúr assemblages. Third, questions relating to the use of material culture in different contexts could be addressed with greater confidence.

We constructed a narrative for each site and micro-region, focusing on archaeologically observable social entities (Siklósi \& Szilágyi, 2016, 2021). In what follows, we present an Early Copper Age settlement and contemporary cemetery: RákóczifalvaBivaly-tó Site 1/C. Because it was most probably fully excavated (i.e. believed to represent the full extent of the coeval settlement and cemetery), it yielded enough data to discuss issues of representation and analytical units. In our study, the labels 'Tiszapolgár' and 'Bodrogkeresztúr' style are used in their traditional meaning, in order to point to the contradictions between the different models and approaches.

\section{Rákóczifalva-Bivaly-Tó Site 1/C}

The Early Copper Age cemetery at Rákóczifalva-Bivaly-tó Site 1/C consists of seventy-nine graves excavated in 20052007 (Figure 1) (Csányi et al., 2010: 24144). An empty zone, $120-140 \mathrm{~m}$ wide, separates the cemetery from its contemporary settlement (Figure 2).

The settlement is located in an area measuring roughly $50 \times 50 \mathrm{~m}$ in the north- western part of the excavation on the first terrace above the flood plain of the river Tisza. Based on the distribution and density of Early Copper Age features, it is likely that most of the settlement was excavated. It consists of thirty features, i.e. pits of different size and shape surrounding three rectangular buildings. A single burial (F542/S892) was found in a pit in the centre of the settlement, approximately $120 \mathrm{~m}$ from the edge of the burial ground.

The burials in the cemetery were arranged in two groups. The western group consisted of sixty-four burials and the eastern group of eleven burials respectively. A row of four graves formed a link between the groups. The graves were organized along SW-NE oriented lines and the burials themselves were oriented SENW. The mortuary practice and grave goods are identical to those found at other contemporary cemeteries on the Great Hungarian Plain. The inhumations were in a crouched position, with males usually laid on their right side, and females on their left. Grave goods consisted mostly of vessels, animal bones (most likely remains of food offerings), ornaments and tools made of stone, copper, and gold. Copper and gold artefacts were used as prestige goods to represent and manipulate individual rank (Csányi et al., 2010: 244-58, 261). Equal proportions of males and females are represented in the cemetery but the children make up only 16.42 per cent of the population; the graves of the youngest especially are absent. Community-wide nutritional deficiencies are likely to be indicated by traces of cribra orbitalia in both sexes and hypoplasia on the teeth. Transverse wear of the teeth, indicating work, was also observed in both sexes. Enthesopathy caused by excessive exercise was frequent among males (Zoffmann, 2015).

Radiocarbon dates from both the settlement and cemetery were calibrated with 


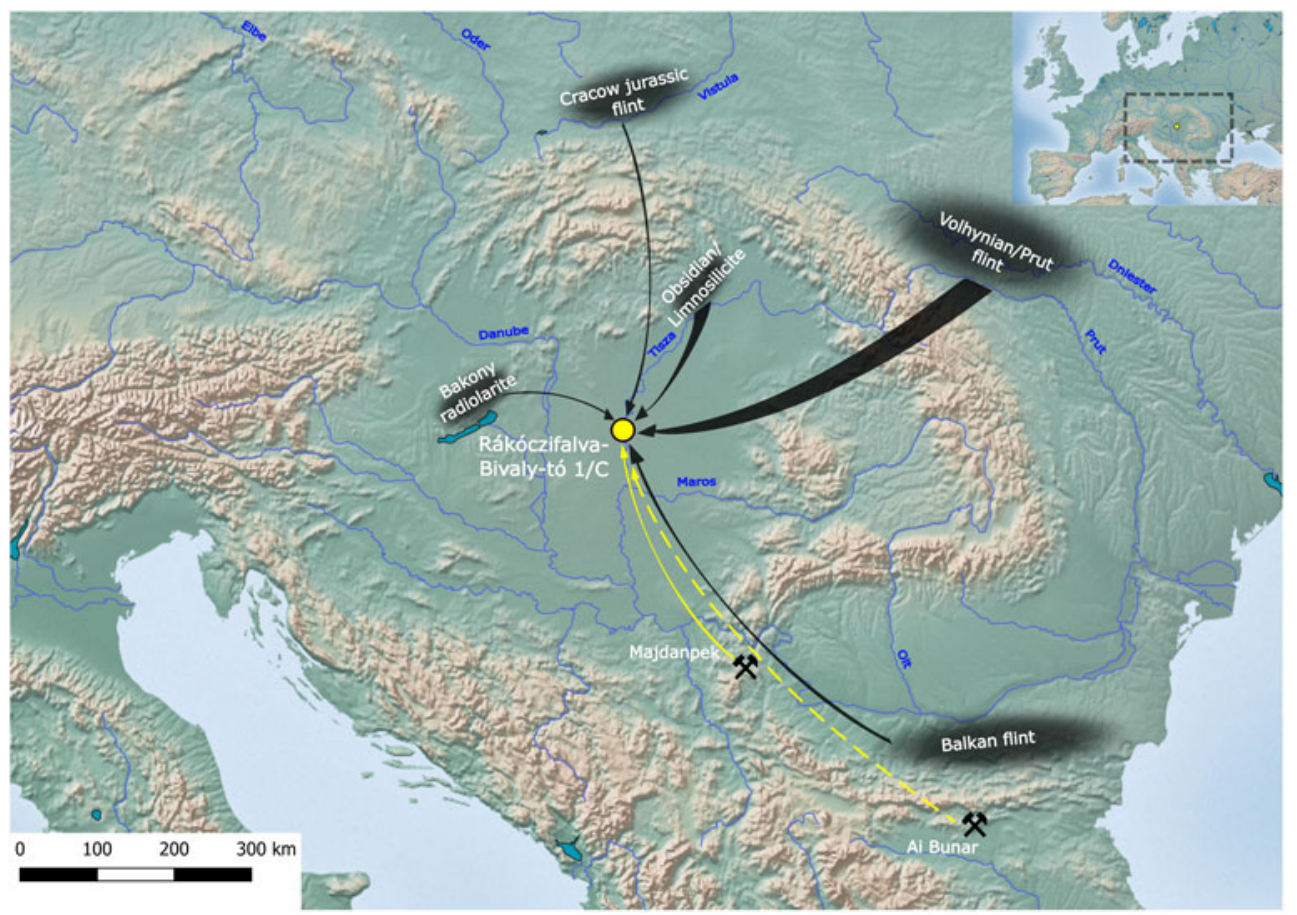

Figure 1. Location of Rákóczifalva-Bivaly-tó Site $1 / C$ and provenance of stone and copper raw materials.

the IntCal13 curve (Reimer et al., 2013) and $\mathrm{OxCal}$ 4.2.4 software (Bronk Ramsey, 2009). Based on the results of Bayesian modelling of these measurements, the beginning of the settlement's use can be estimated at 4380-4285 cal BC (at 68.3\% probability) and its abandonment at $4295-$ 4125 cal BC (at $68.3 \%$ probability) after a use of span of 15-150 years (at 68.3\% probability) (Siklósi \& Szilágyi, 2021).

A chronological distinction between the grave groups is possible. The western group may have begun in $4345-4270 \mathrm{cal}$ $B C$ (at $68.3 \%$ probability) and was in use until 4350-4225 cal BC (at 68.3\% probability); its span of $0-50$ years (at $68.3 \%$ probability) was therefore brief. The eastern group yielded slightly more recent dates. It started in 4250-4110 cal BC (at 68.3\% probability) and people were buried there until 4150-4015 cal BC (at 68.3\% probability), which represents a span of $0-75$ years (at $68.3 \%$ probability). According to the Difference command in OxCal, the settlement and the cemetery could have started at the same time, but, after the abandonment of the settlement, the smaller, eastern grave group could have remained in use (Figure 3) (Csányi et al., 2010: 263; Siklósi \& Szilágyi, 2021).

\section{Pottery styles}

Since pottery styles are among the criteria used to distinguish the Tiszapolgár from the Bodrogkeresztúr culture, we paid particular attention to the evaluation of the ceramic material. The pottery from the settlement is fragmentary: 2314 sherds (of which 1173 sherds were diagnostic) were found, belonging to 2084 vessels. The vessels were usually of good quality, with thirty per cent of the fragments burnished. 


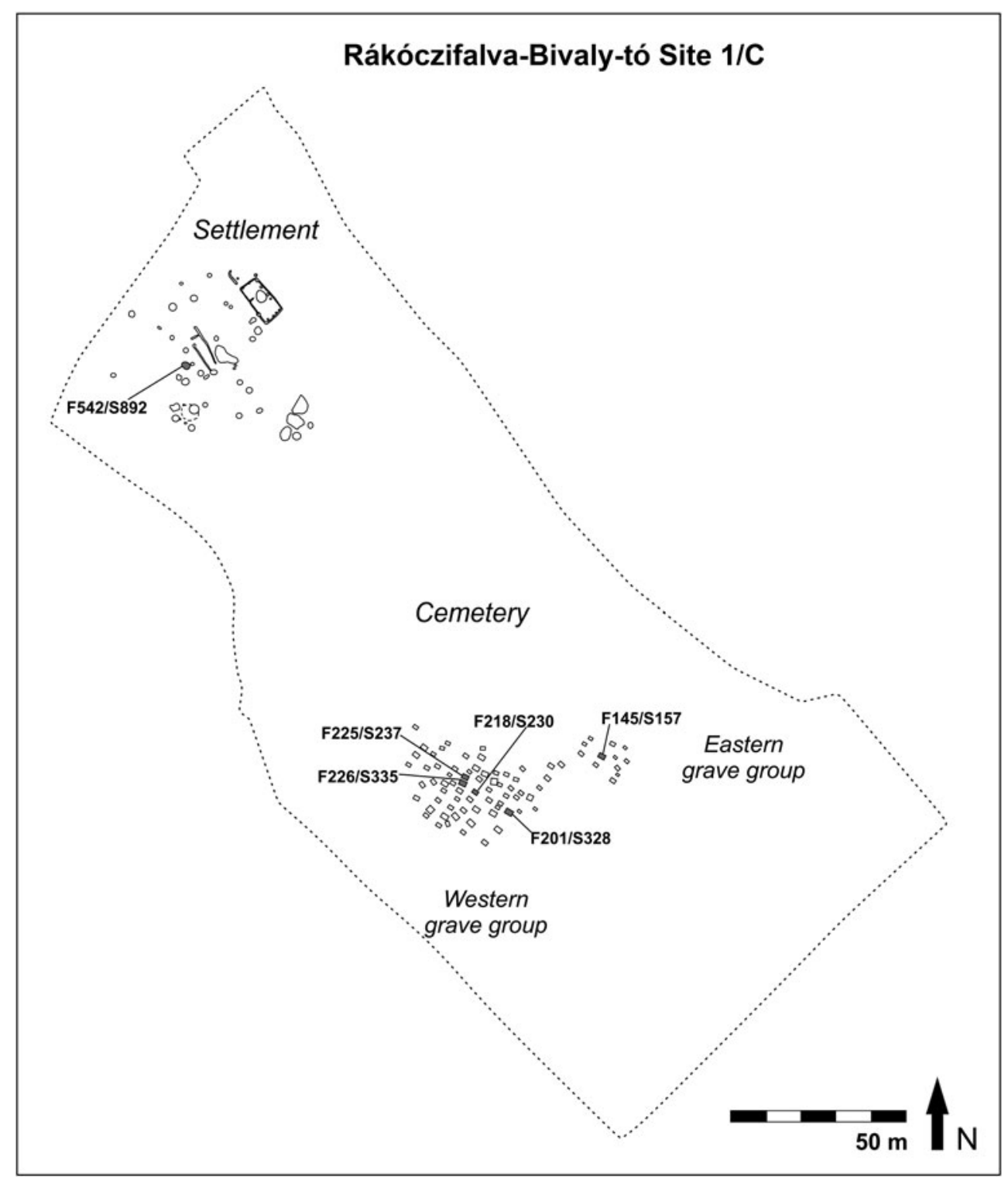

Figure 2. Plan of the site.

Comparing the pottery from the cemetery with that from the settlement reveals a significant difference (Figure 4). Bowls constitute seventy per cent of the settlement's vessel types but make up only twenty-nine per cent of the cemetery's ceramics. Vessel bases differ considerably between settlement and cemetery: fortynine per cent (113 fragments) of the base sherds found in the settlement belonged to flat bases and fifty-one per cent (116 sherds) to pedestals, whereas in the cemetery only eight pedestalled vessels were found (i.e. ninety-six per cent flat bases). In the settlement, jars account for nine per cent of the assemblage whereas they occur very rarely in the cemetery; as for flowerpot-shaped vessels, eight per cent were 

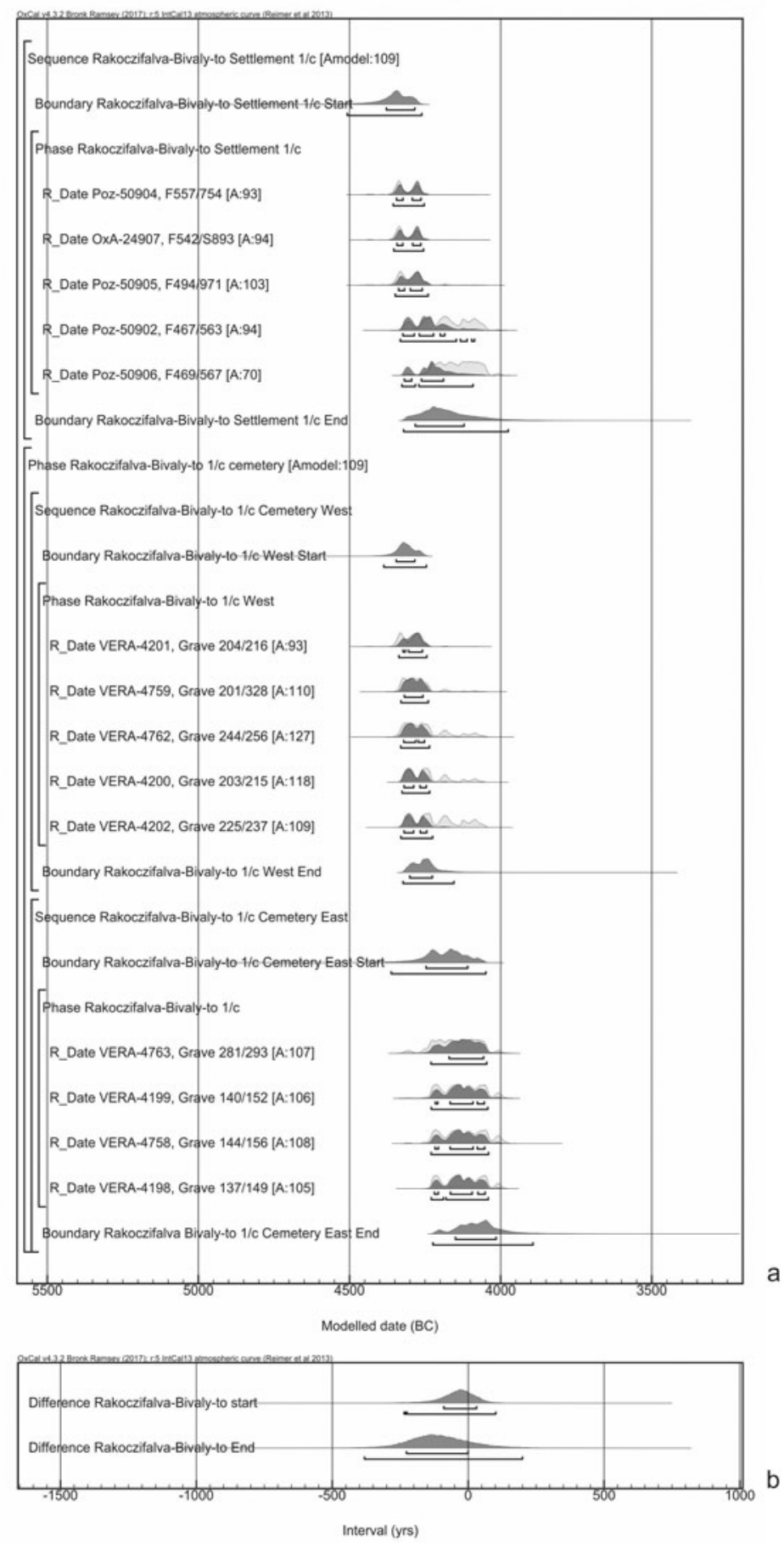

Figure 3. a) Probability distributions of radiocarbon dates from Rákóczifalva-Bivaly-tó Site $1 / C$. The square brackets on the left-hand side, along with the OxCal keywords, define the model; b) Difference refers to the start of the settlement and cemetery and the end of the settlement and cemetery, respectively. 


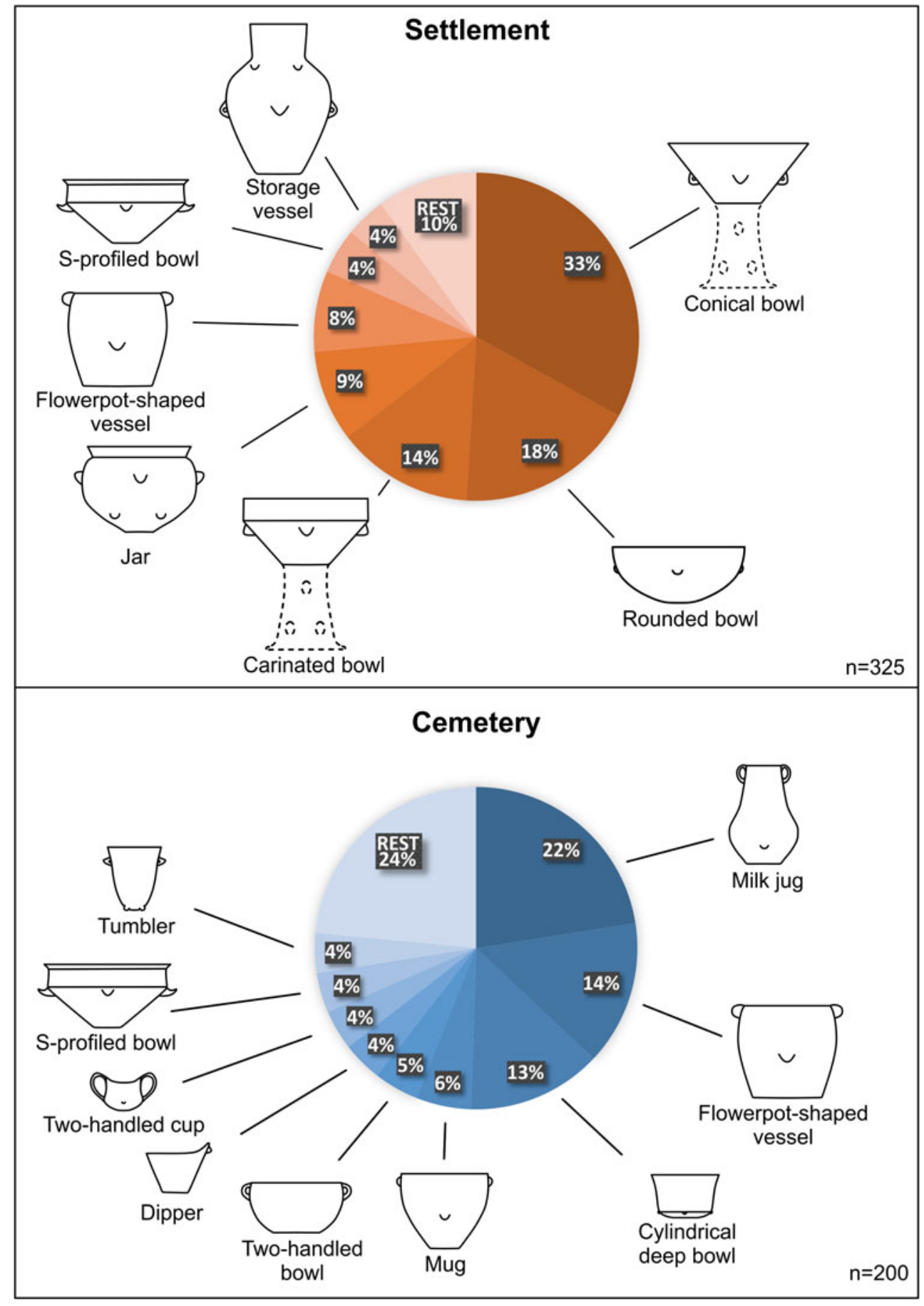

Figure 4. Distribution of pottery types from the settlement and cemetery. 
found in the settlement, compared to fourteen per cent in the cemetery. Storage vessels made up four per cent of the settlement assemblage, while tumblers accounted for four per cent in the cemetery. In the settlement, eight further vessel types share the remaining ten per cent. A precise stylistic classification of the pottery is not possible, because some of the incised decorative motifs can be assigned to the Tiszapolgár style and others to the Bodrogkeresztúr style. Stylistically different sherds were commonly found together in one feature.

The proportion of fine ware in the cemetery is much lower than in the settlement. Milk jugs were most frequently encountered in the graves (twenty-two per cent), followed by flowerpot-shaped vessels and cylindrical deep bowls with conical bases. These three types of vessel formed the most common assemblage in the graves: twenty-six out of the seventynine graves contained at least two such vessels in various combinations. None of the remaining twenty-six vessel types exceed five per cent. Mugs, dippers, twohandled bowls, conical and S-profiled bowls, two-handled cups, and tumblers were represented by five to ten pieces, while many more types or variants were represented by only one or two vessels.

In contrast to the thirty decorated vessels (fifteen per cent) from the cemetery, 270 sherds (twenty-three per cent) from the settlement had impressions or incisions. While those from the settlement are of excellent quality, twenty per cent of vessel decorations in the cemetery are poorly executed. Both classic Tiszapolgár and Bodrogkeresztúr decorations can be found in the burial ground.

Forty-five milk jugs were placed in the burials, while only four pieces were found in the settlement. The same proportion can be observed among the two-handled cups (eight examples in the cemetery, only one in the settlement) and large-handled jugs (three pieces from graves and none from settlement features). Some unique pottery shapes occur only in the cemetery, such as a small spherical vessel, a biconical pot, or a pot with a Scheibenhenkel (discshaped handle) application.

During the period of use of the settlement, no changes in the proportions of vessel shapes could be observed, but there were changes in decoration. This can be interpreted as a slow, constant change in which the proportions shift, since no sharp boundaries of distinct phases could be identified (Szilágyi, 2016: 398). In the cemetery, vessels of both Tiszapolgár and Bodrogkeresztúr styles (and even Scheibenhenkel that characterizes the Hunyadihalom style) appear in contemporaneous graves of the western grave group.

\section{Copper}

In contrast to the eighteen copper artefacts (some illustrated in Figure 5) and nine gold ornaments found in the cemetery (Csányi et al., 2010: 258-59), neither metal artefacts nor finds referring to local metallurgical activity were recovered from the settlement.

Two axes were found in the western grave group. A Şiria-type hammer axe (Figure 5 no. 7) and a gold cone (Figure 6 1) were put into the grave of a 34-38year-old man (F201/S328), and a Jászladány-type axe-adze was discovered in a symbolic burial without human remains (F218/S230, Figure 5 8) (Csányi et al., 2010: 256, 262, fig. 8). Both graves contained Bodrogkeresztúr-style pottery. The copper bracelets from the graves of the western group include a large, open-ended copper bracelet (Figure 5 1) found around the right forearm of a 26-30 year-old man, whose grave contained Tiszapolgárstyle vessels (F225/S237). Only one grave, 


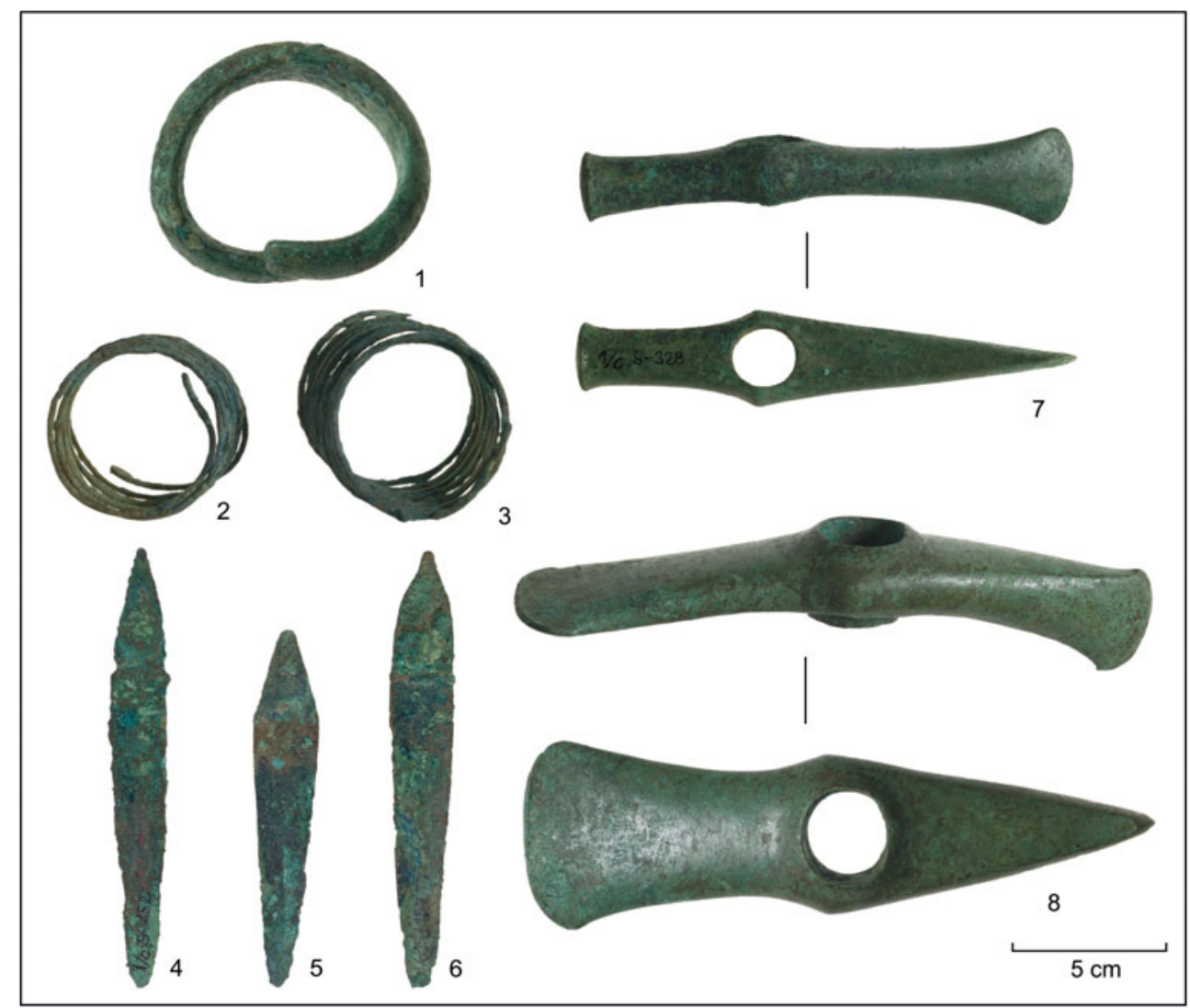

Figure 5. Copper artefacts from the cemetery. 1: bracelet from F225/S237; 2-3: spiral bracelets from F226/S335; 4-6: daggers from F140/S152 (4), F141/S153 (5), and F145/S157 (6); 7: Siria-type hammer axe from F201/S328; 8: Jászladány-type axe-adze from F218/S230. Photographs by permission of K. Kozma.

that of an adult woman, contained both copper and gold ornaments, accompanied by Bodrogkeresztúr-style pottery. She wore multiple spiral bracelets on both wrists (Figure 5 2-3) and gold pendants on her temples (F226/S335, Figure 6 5) (Csányi et al., 2010: 252, figs 9 and 11).

The western grave group was considerably larger than its eastern counterpart, but less than a quarter of the western graves contained metal grave goods. Half of the burials in the smaller, eastern grave group contained copper objects, while no gold was found in this cluster. The copper objects of the eastern group differed typologically from those of the western group.
Burials of adult men accompanied by daggers and Bodrogkeresztúr-style pottery were concentrated in the eastern, more recent group (Csányi et al., 2010: 258). Small pins or awls were found only in adult male graves, while tiny beads were recovered in children's and adult female graves.

The chemical composition and lead isotope analyses indicates that the objects were made of high-purity copper ore. The similarity in the material of the two axes suggests that they may have come from the same source, most likely to be Majdanpek. The composition and lead isotope ratio of the spiral bracelet pair from Grave F226/S335 were almost 


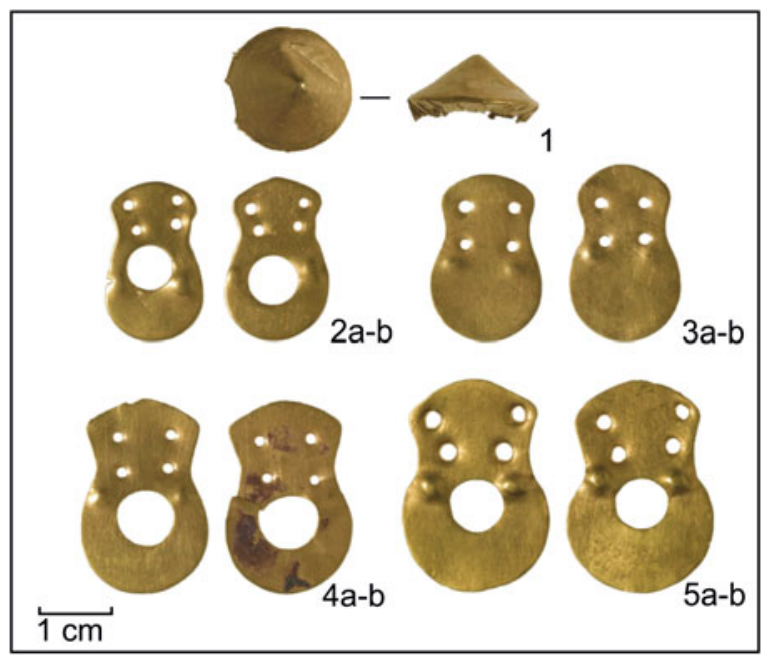

Figure 6. Gold ornaments from the cemetery. 1: cone from F201/S328; 2-5: pendants from F205/ S217 (2), F231/S326 (3), F207/S321 (4), and F226/S335 (5). Photographs by permission of K. Kozma.

identical; presumably they were simultaneously made from one source, perhaps in Majdanpek or Ai Bunar (Figure 1), and brought to the Tisza region together. The higher concentration of arsenic in two daggers differentiate them from the rest of the analysed copper artefacts from the cemetery; their composition suggests $\mathrm{Ai}$ Bunar as a possible source (Siklósi \& Szilágyi, 2019).

\section{Gold}

Apart from the male and female graves mentioned above (the male burial F201/ S328 with a gold cone, and the female burial F226/S335 with gold pendants), three female burials contained Magyartéstype golden pendants (Figure 6 2-4) (Csányi et al., 2010: 259, fig. 5). These pendants were found around the skull, most probably forming part of a headdress or hair ornament.

Despite being flat, pendants were cast. Traces of casting are visible on the surface of the objects, studied in detail using a digital 3D microscope (Keyence VHX6000), as well as a scanning electron microscope (JEOL IT500HR LA). The front of the pendants is finely polished, while the back is rough, with several micro-traces and casting patterns. The silica particles enclosed in the gold surface (Figure 7a), and the characteristic surface structure (Figure 8a), also indicate casting. Narrower and wider grooves are visible on the surface of the pendants, indicating secondary processing (sanding and burnishing) (Figures 7b, 8c). The small suspension holes could have been made by a copper or bone awl or punch (Figure 7c). The edge of the holes was ground in most cases (Figure 8b). The little protuberances were impressed from the back.

The elemental composition of the gold objects was determined by particle-induced X-ray emission (PIXE) (Rajta et al., 1996; Uzonyi et al., 2001; Kertész et al., 2005). The gold content of the pendants varies between ninety-one and ninety-four per cent, while the silver content was found to be between six and eight per cent. The copper and iron content varied between 0.3 

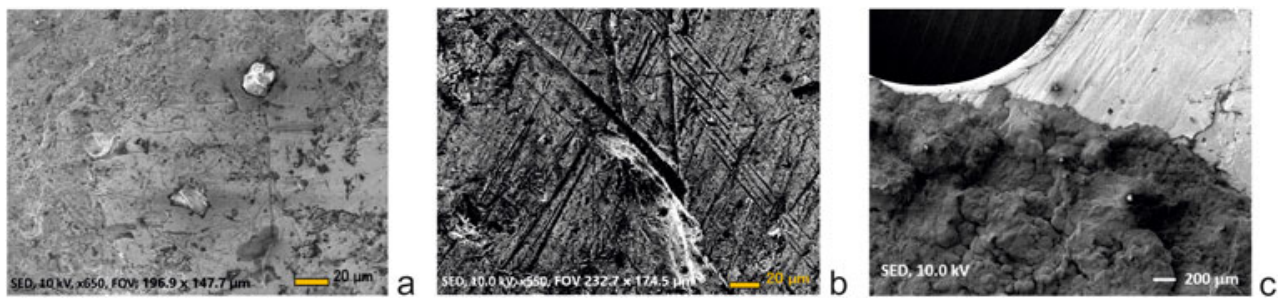

Figure 7. SEM images of the gold pendants. a) detail of the pendant's surface (grave good no. 1) with enclosed silica (quartz) grains from Grave 226/335; b) detail of the back of the pendant (grave good no. 1) with traces of secondary crafting from Grave 231/326; c) detail of the back of the same pendant with traces of non-organic residue.
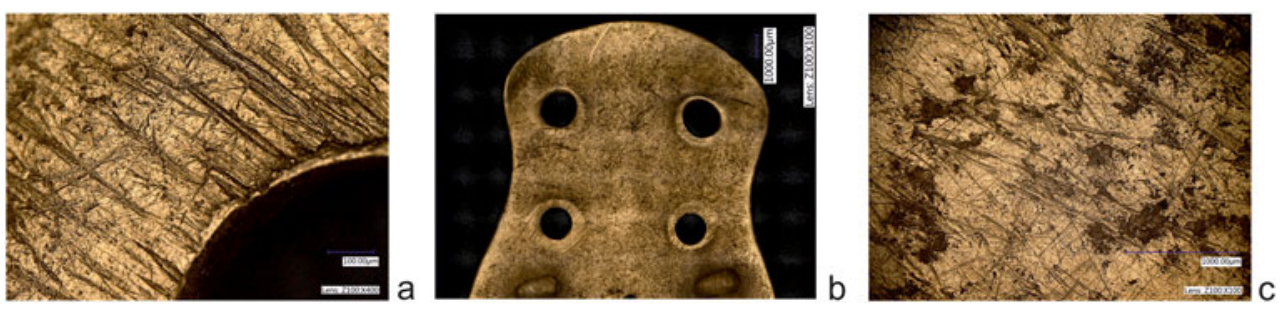

Figure 8. Keyence 3D microscopy images of the gold objects. a) traces of secondary crafting on the back of the pendant (grave good no. 7) from Grave 231/326; b) back of the same pendant; c) detail of the surface of the pendant (grave good no. 9) from Grave 226/335.

and $0.6 \mathrm{wt} \%$ and 400 and $700 \mathrm{ppm}$, respectively (Table 1). Generally, the artefacts have a similar elemental composition, which might be attributed to a common origin in terms of raw materials and time of production. However, some chemical elements, which may play an important role in provenance analysis, were found below the limit of detection ( $\mathrm{Sn}<260 \mathrm{ppm}$, $\mathrm{Sb}<220$ ppm, $\mathrm{Te}<110$ ppm, $\mathrm{Hg}<1000$ ppm, $\mathrm{Pb}<150 \mathrm{ppm}$ ) and detection of some fingerprinting elements (platinum and iridium) was hindered by the massive presence of gold.

A comparison of the results obtained from Rákóczifalva with the data from the Cheile Turzii site (the first Copper Age goldsmithing workshop known from the Carpathian Basin) and with Transylvanian gold mineral sources (Lazarovici et al., 2015) reveals considerable differences. Whereas high silver and low copper contents are generally characteristic of
Transylvanian gold, primarily owed to the hydrothermal origin of the gold from the Transylvanian Ore Mountains (Munții Metaliferi) (Hauptmann et al., 1995; Cojocaru et al., 2006; Constantinescu et al., 2008: 2326; Pop et al., 2011), the Rákóczifalva gold objects contain less silver and more copper. The usefulness of comparing these artefacts to mineral sources is however limited, due to the lack of information on essential trace elements in our case, and because changes in elemental composition occur during the melting process in general.

\section{Lithics}

Altogether 108 pieces were analysed from forty-six graves, of which sixty items can be associated with the Volhynian/Prut type raw material (Figure $92-4$ ), which is found 400-450 kilometres east-northeast 
Table 1. Elemental composition of gold artefacts measured by PIXE. The concentrations of the main components $(\mathrm{Au}, \mathrm{Ag}, \mathrm{Cu})$ are given in wt\%, while the concentrations of trace elements are in $p p m$. The uncertainty of the measurement is five per cent for the main components and 15-25 per cent for the trace elements.

\begin{tabular}{|c|c|c|c|c|c|c|c|c|}
\hline $\begin{array}{l}\text { ID on } \\
\text { Fig. } 6\end{array}$ & $\begin{array}{l}\text { Feature/ } \\
\text { Strat. }\end{array}$ & Type & $\begin{array}{c}\text { Au conc } \\
\text { wt } \% \text {. }\end{array}$ & $\begin{array}{c}\text { Ag conc. } \\
\text { wt } \%\end{array}$ & $\begin{array}{c}\text { Cu conc. } \\
\text { wt } \%\end{array}$ & $\begin{array}{c}\text { Fe conc. } \\
\text { ppm }\end{array}$ & $\begin{array}{c}\text { Ni conc. } \\
\text { ppm }\end{array}$ & $\begin{array}{c}\text { As conc. } \\
\text { ppm }\end{array}$ \\
\hline 1 & $201 / 328$ & Cone & 92.92 & 6.08 & 0.38 & 480 & 130 & 300 \\
\hline $2 a$ & $205 / 217$ & Magyartés-type pendant & 92.26 & 6.70 & 0.35 & 470 & 140 & 310 \\
\hline $2 \mathbf{b}$ & $205 / 217$ & Magyartés-type pendant & 91.34 & 7.77 & 0.43 & 440 & 120 & 200 \\
\hline $3 \mathbf{a}$ & $231 / 326$ & Magyartés-type pendant & 91.62 & 7.24 & 0.41 & 430 & 110 & 400 \\
\hline $3 \mathbf{b}$ & $231 / 326$ & Magyartés-type pendant & 92.71 & 6.11 & 0.63 & 490 & 120 & 140 \\
\hline $4 a$ & $207 / 321$ & Magyartés-type pendant & 92.99 & 5.98 & 0.35 & 460 & 160 & 330 \\
\hline $4 b$ & $207 / 321$ & Magyartés-type pendant & 93.15 & 5.87 & 0.31 & 510 & 170 & 230 \\
\hline $5 a$ & $226 / 335$ & Magyartés-type pendant & 92.92 & 5.96 & 0.46 & 670 & 120 & 300 \\
\hline $5 \mathbf{b}$ & $226 / 335$ & Magyartés-type pendant & 92.42 & 6.33 & 0.46 & 580 & 100 & 210 \\
\hline
\end{tabular}

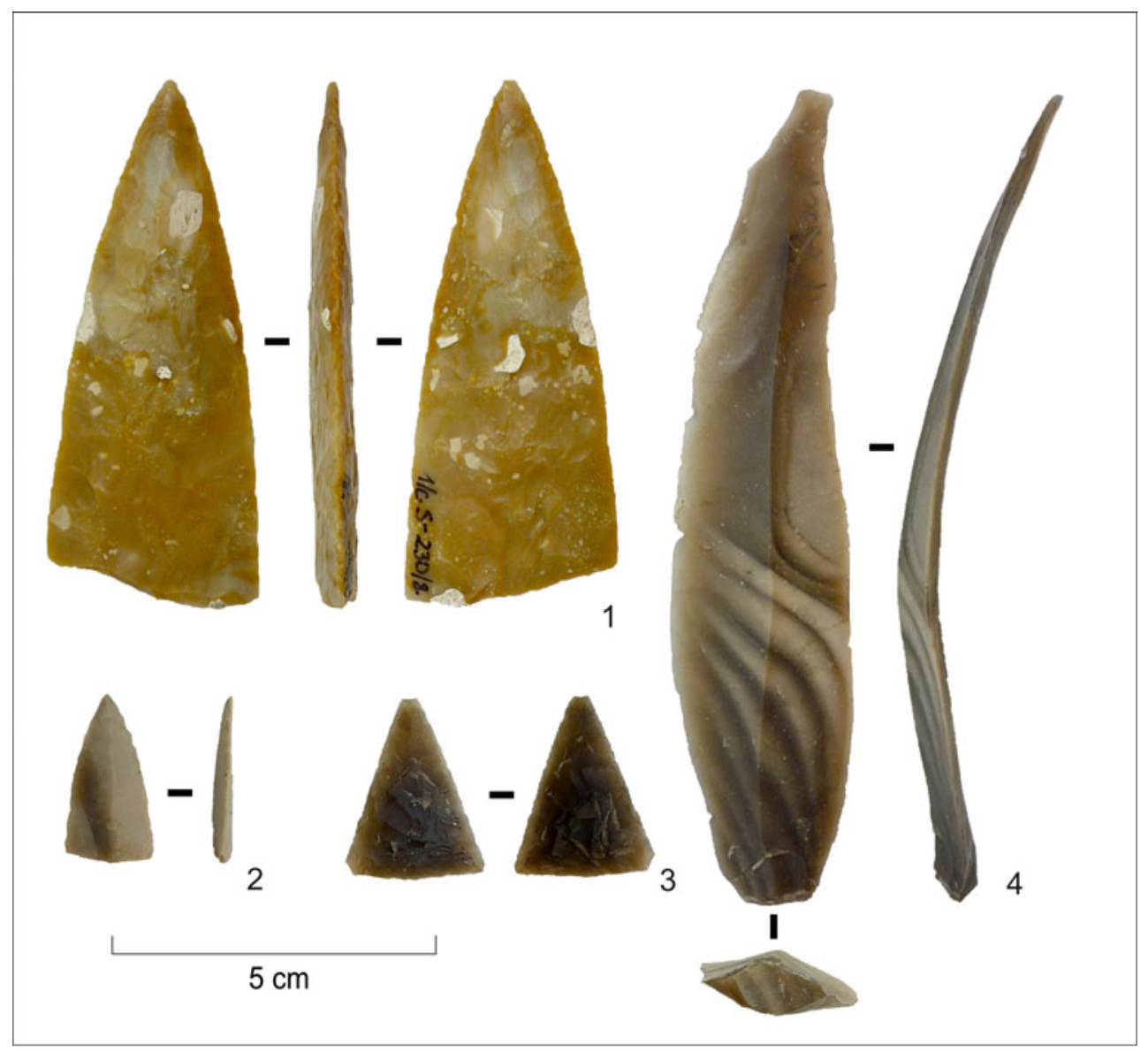

Figure 9. Selected chipped stone tools from Grave F218/S230. 1: bifacial Balkan leafpoint; 2-3: Volbynian points, 4: Volbynian blade. 
of Rákóczifalva (Kaczanowska, 1985; Biró, 1998; Rhyzov et al., 2005). Thirty pieces are made of either obsidian or limnosilicite from the Tokaj Mountains, located 150200 kilometres north east of the Middle Tisza region (Biró, 1998, 2018; Mester \& Faragó, 2016). Four radiolarite pieces are of western origin, from the Transdanubian Bakony Mountains (Biró, 1998; Szilasi, 2017). One blade was probably made of Cracow Jurassic flint (Krajcarz et al., 2012), while the raw material of a segment is linked to the Banat region (Băltean, 2011). The rest is made of various flint types that are difficult to identify. Among these, one extraordinary piece, a bifacially retouched leafpoint from the symbolic burial F218/S230, is made of a particular, orange-brown, white-spotted, fine flint, associated with a type of Balkan flint found more than 800 kilometres away in Bulgaria (Gurova et al., 2016) (Figures 1 and 9 1).

Only a few pieces had cortex on their surface, regardless of the raw material used. It suggests that the raw material was carefully prepared and that knapping activity was conducted off-site, since the settlement contained an insignificant quantity of knapped material (eight pieces). The colour, texture, and markings of several Volhynian flint blades indicate that they were removed from the same nodule; however, during the examination and refitting test no conjoining pieces could be identified. Despite the absence of local knapping activity, it is possible that these pieces came from the same workshop.

The knapped assemblage from the Rákóczifalva cemetery contained neither pre-cores nor cores from any of the raw material types, and only two unretouched flakes were recovered. The technological characteristics of blades made of different raw materials do not differ from each other, suggesting a similar manufacturing tradition. The only difference is in the total length of the complete blades: the Volhynian blades could exceed $170 \mathrm{~mm}$, while the limnosilicite pieces hardly reached $90 \mathrm{~mm}$. Two broken blades were put into two graves; both were most probably broken during production (languette breakage). The fact that none of the broken blades showed traces of use or intentional fragmentation indicates that they were made and brought to the site for the funeral and not used for other activities.

Most lithic remains (sixty-three pieces) can be considered as tools. The most abundant tool type consists of laterally retouched blades (twenty-six pieces). Despite being carefully retouched, these blades do not seem to be worn; sometimes, their edges appear to be fresh. A fragment of a bifacial leafpoint suggests typological affinities with the Balkans (Hansen et al., 2006: 371-77; Boyadzhiev, 2014: 175-76, figs 36-40). Obsidian was used almost exclusively for small bifacial points.

\section{Discussion}

No feature in the settlement appears to indicate a particular function other than everyday life. The fine, well-made pottery can be related to daily household activities and displays traits characteristic of local traditions. Finds or evidence of activity that would prove long-distance connections, or the local processing of raw materials from distant sources, are absent. The settlement finds show a high degree of homogeneity, and neither social nor other differences were observed.

The radiocarbon data indicate that the grave found in the settlement was contemporary with the first graves in the cemetery. This suggests that the cemetery was probably already in use by the time a burial was added to the settlement. Its funerary rite is identical to that used in the 
cemetery but some traits are ambiguous: laying the body on the left side is a female characteristic, whereas the chipped blade is more of a male characteristic. According to Zoffmann's (2011) anthropological study, the deceased was a 23-29 year-old male. Strikingly, four of the six vessels found in that grave were finely decorated, making the assemblage more similar to the pottery recovered in the settlement. Such a burial might have been determined by the community's rules or the individual's identity, which dictated that this person was to be buried in the settlement instead of in the cemetery.

The consciously selected material culture recovered from the cemetery shows another facet of the community. Raw materials obtained over long distances play an important role among the grave goods. Differences in the gender, age, and rank of individuals are prominent elements of the funeral rite. In addition to the metal objects, the long Volhynian flint blades and the Balkan flint leafpoint can be linked with such individual differences.

The internal organization of the cemetery revolved around central graves. The symbolic burial F218/S230 in the centre of the western grave group was surrounded by an empty area. Taking its grave goods into consideration (milk jug, a Jászladány-type axeadze, long Volhynian flint blades, a large Balkan flint leafpoint, triangular points, and a boar mandible), this burial may have symbolized long-distance relations.

According to absolute dating, there is a chronological difference between the two spatial grave groups. However, this difference cannot be seen in the use of pottery styles, as all three of them can be found in coeval graves of the (older) western group. This indicates a simultaneous use of different stylistic elements that were previously thought to be chronological markers. Copper daggers occur only in the eastern group but gold ornaments were not found here. In the centre of this group, a man was buried in a burial pit with postholes at its four corners and his grave goods consisted of a copper dagger, a long flint blade, three vessels, and food (F145/ S157). Comparing the pottery of the western and eastern groups, it is noticeable that only three of the eleven graves in the eastern group do not contain milk jugs and the vast majority of the pots are undecorated. This may indicate the existence of a special social group.

The traditional differences used to define the Tiszapolgár and Bodrogkeresztúr cultures are more prominent in the deliberately selected material culture of the cemetery. The graves can indeed often be assigned to these units based on the cooccurrence of copper axe-adzes, copper daggers, gold pendants, milk jugs and other Bodrogkeresztúr-style pottery, or copper bracelets associated with Tiszapolgár-style pottery. This difference is hardly evident in the settlement assemblage.

Would our results have been the same had we used a more traditional, culturebased approach? We would have dated the site to around the transition period between Tiszapolgár and Bodrogkeresztúr, and the pottery and metal artefacts found in the graves would have led us to suppose a gradual transition in the cemetery, starting in the Tiszapolgár period continuing through a transitional phase and ending in the Bodrogkeresztúr period. Moreover, we would have dated the end of the cemetery to the final phase of the Bodrogkeresztúr culture based on the occurrence of a Scheibenhenkel. In contrast to the long use of the cemetery, the settlement would have been defined as a hamlet of short duration, dated to the Tiszapolgár-Bodrogkeresztúr transition. This approach would have overemphasized the unilinear, temporal axis of stylistic change, ignoring the various other explanatory possibilities beyond stylistic differences. A chronological and cultural 
classification based on the use of pottery styles and metal objects would have made it impossible to recognize the contemporaneity of graves containing different styles. Merely knowing the AMS radiocarbon dates and using Bayesian modelling is insufficient. If we had a priori built into our model the Tiszapolgár and Bodrogkeresztúr cultures as consecutive phases, the result would have been a circular argument (cf. Brummack \& Diaconescu, 2014: 245-46). We tested the possibility of consecutive phases during the modelling of more than eighty AMS dates from the Great Hungarian Plain, and showed that the strict temporal succession of the Tiszapolgár and Bodrogkeresztúr styles cannot be maintained (Siklósi \& Szilágyi, 2021).

One of the main weaknesses of the concept and definition of archaeological cultures is its generalizing nature. Had we considered the Tiszapolgár and Bodrogkeresztúr cultures as homogeneous, monothetic units, we would not have been able to build a model in which a duality of the material culture of the Rákóczifalva settlement and cemetery becomes perceptible. By avoiding generalizations as far as possible, we were able to reveal two types of (self-)identification in two different contexts, giving, we believe, a more realistic image of this community.

The model set up for the interpretation of the Rákóczifalva assemblage is valid only for Rákóczifalva. If we were to project these results onto other sites, we would be making the mistake we want to avoid, i.e. generalization and homogenization. Were these rules valid elsewhere? This can only be determined after similar, in-depth, sitefocused analyses of further sites. We believe that the intertwined network of social interactions behind the diversity of the material culture and cultural traditions, and the relationship between the small Early Copper Age communities that once lived on the
Great Hungarian Plain, can only be explored through this approach.

\section{Conclusion}

The Early Copper Age settlement and cemetery of Rákóczifalva-Bivaly-tó Site 1/C reveals a duality in the use of material culture recovered from two different archaeological contexts.

Despite their spatial and temporal closeness, the differences between the settlement and cemetery show how the various elements of their material culture were used in diverse ways. This could be apprehended in all archaeological contexts. The cemetery is suitable for examining the smallest entity, the individual and his or her age, gender, and rank, but also for investigating distant connections and the display of larger social groups. It is indeed in the cemetery that we identified such long-distance relationships, whereas no trace of such links or distinction between style could be found in the settlement.

The site-based approach made all these observations possible. Such a detailed story could not have emerged by putting Rákóczifalva into a model based on archaeological culture as an a priori social entity. Our case study highlights the methodological issues associated with archaeological periods, in which, due to a lack of information, we are compelled to focus exclusively on either settlement or burial data.

\section{Acknowledgements}

The project was supported by the Hungarian Thematic Excellence Programme 2020. The analyses of gold artefacts were supported by the GINOP-2.3.3-15-2016-00029 project. We wish to express our gratitude to Marietta Csányi, Judit Tárnoki, and Pál Raczky for allowing us to study the 
Rákóczifalva-Bivaly-tó Site 1/C. We are grateful to Dušan Boric for sharing the date from Rákóczifalva-Bivaly-tó Site 1/C obtained at the Oxford Radiocarbon Accelerator Unit (NRCF programme NF/ $2010 / 2 / 3$ funded by the NERC). Zsuzsanna Siklósi's work was supported by the Bolyai János Research Fellowship. We are also grateful to Elisabetta Starnini for helping us with the raw material analysis of the bifacial leafpoint. Finally, we thank the reviewers and editors for their constructive comments and work.

\section{REFERENCES}

Bailey, G. 2007. Time Perspectives, Palimpsests, and the Archaeology of Time. Journal of Anthropological Archaeology, 26: 198-223.

Băltean, I.C. 2011. Some Remarks on the Rock Types Used in Prehistory. In: F. Draşovean \& B. Jovanović, eds. The Prehistory of Banat. Bucharest: Editura Academiei Române, pp. 32-33.

Bintliff, J. ed. 1991. The Annales School and Archaeology. Leicester \& London: Leicester University Press.

Biró, K.T. 1998. Lithic Implements and the Circulation of Raw Materials in the Great Hungarian Plain During the Late Neolithic Period. Budapest: Hungarian National Museum.

Biró, K.T. 2018. More on the State of Art of Hungarian Obsidians. Archeometriai Múhely, 40: 213-23.

Bognár-Kutzián, I. 1963. The Copper Age Cemetery of Tiszapolgár-Basatanya (Archaeologia Hungarica 42). Budapest: Akadémiai kiadó.

Bognár-Kutzián, I. 1972. The Early Copper Age Tiszapolgár Culture in the Carpathian Basin (Archaeologia Hungarica 48). Budapest: Akadémiai kiadó.

Bökönyi, S. 1988. History of Domestic Mammals in Central and Eastern Europe. Budapest: Akadémiai kiadó.

Boyadzhiev, K. 2014. Vuoruzhenie prez Khalkolita v bulgarskite zemi. Weapons from the Chalcolithic period in Bulgaria (Disertatsii/Dissertations 9). Sofia: National Institute of Archaeology with Museum.
Braudel, F. 1967. Civilisation matérielle et capitalisme (XVe-XVIIIe siècle): Tome I. Paris: A. Colin.

Bronk Ramsey, C. 2009. Bayesian Analysis of Radiocarbon Dates. Radiocarbon, 51: 337-60.

Brummack, S. \& Diaconescu, D. 2014. A Bayesian Approach to the AMS Dates for the Copper Age in the Great Hungarian Plain. Prähistorische Zeitschrift, 89: 242-60.

Cojocaru, V., Constantinescu, B. \& Bugoi, R. 2006. Trace Elements in Transylvanian Gold Nuggets. Romanian Journal of Mineral Deposits E Romanian Journal of Mineralogy, 82: 171-74.

Constantinescu, B., Bugoi, R., Cojocaru, V., Radtke, M., Calligaro, T., Salomon, J., et al. 2008. Micro-SR-XRF and MicroPIXE Studies for Archaeological Gold Identification: The Case of Carpathian (Transylvanian) Gold and of Dacian Bracelets. Nuclear Instruments and Methods in Physics Research Section B: Beam Interactions with Materials and Atoms, 266: 2325-28.

Csányi, M., Raczky, P. \& Tárnoki, J. 2010. Das kupferzeitliche Gräberfeld von Rákóczifalva-Bagi-föld in Ungarn. Das Altertum, 55: 241-70.

Frieman, C.J. \& Hofmann, D. 2019. Present Pasts in the Archaeology of Genetics, Identity, and Migration in Europe: A Critical Essay. World Archaeology, 51: 528-45.

Furholt, M. 2008. Pottery, Cultures, People? The European Baden Material Re-examined. Antiquity, 82: 617-28.

Furholt, M. 2019. Re-integrating Archaeology: A Contribution to aDNA Studies and the Migration Discourse on the 3rd Millennium BC in Europe. Proceedings of the Prehistoric Society, 85: 115-29.

Giblin, J.I. \& Yerkes, R.W. 2016. Diet, Dispersal, and Social Differentiation During the Copper Age in Eastern Hungary. Antiquity, 90: 81-94.

Giblin, J.I., Knudson, K.J., Bereczki, Z., Pálfi, G. \& Pap, I. 2013. Strontium Isotope Analysis and Human Mobility During the Neolithic and Copper Age: A Case Study from the Great Hungarian Plain. Journal of Archaeological Science, 40: 227-39. 
Graves-Brown, P., Jones, S. \& Gamble, C. eds. 1996. Cultural Identity and Archaeology. London \& New York: Routledge.

Gurova, M., Andreeva, P., Stefanova, E., Stefanov, Y., Kočić, M. \& Borić, D. 2016. Flint Raw Material Transfers in the Prehistoric Lower Danube Basin: An Integrated Analytical Approach. Journal of Archaeological Science: Reports, 5: 422-41.

Gyucha, A. 2015. Prehistoric Village Social Dynamics: The Early Copper Age in the Körös Region. Budapest: Archaeolingua.

Gyucha, A., Parkinson, W.A. \& Yerkes, R.W. 2009. A Multi-Scalar Approach to Settlement Pattern Analysis: The Transition from the Late Neolithic to the Early Copper Age on the Great Hungarian Plain. In: T.L. Thurton \& R. B. Salisbury eds. Reimagining Regional Analyses: The Archaeology of Spatial and Social Dynamics. Newcastle upon Tyne: Cambridge Scholars, pp. 100-29.

Hansen, S., Dragoman, A., Reingruber, A., Gatsov, I., Görsdorf, J. \& Nedelcheva, P. 2006. Der kupferzeitliche Siedlungshügel Pietrele an der Unteren Donau. Eurasia Antiqua, 11: 341-93.

Hauptmann, A., Rehren, T. \& Pernicka, E. 1995. The Composition of Gold from the Ancient Mining District of Verespatak/ Roşia Montana, Romania. In: G. Morteani \& J.P. Northover, eds. Prehistoric Gold in Europe. Dordrecht, Boston \& London: Kluwer Academic, pp. 369-81.

Hoekman-Sites, H.A. \& Giblin, J.I. 2012. Prehistoric Animal Use on the Great Hungarian Plain: A Synthesis of Isotope and Residue Analyses from the Neolithic and Copper Age. Journal of Anthropological Archaeology, 31: 515-27.

Hofmann, D. 2015. What Have Genetics Ever Done for Us? The Implications of aDNA Data for Interpreting Identity in Early Neolithic Central Europe. European Journal of Archaeology, 18: 454-76.

Hofmann, D. 2019. Archaeogenetics and Theory Challenges and Convergences. Current Swedish Archaeology, 27: 133-40.

Kaczanowska, M. 1985. Robstoffe, Technik und Typologie der neolithischen Feuersteinindustrien im Nordteil des Flussgebietes der Mitteldonau, Warszawa: Państwowe Wydawnictwo Naukowe.

Kalicz, N. 1988. The New Results of the Investigation on the Hungarian Copper Age. Rassegna di Archeologia, 7: 75-103.
Kertész, Zs., Szikszai, Z., Uzonyi, I., Simon, A. \& Kiss, Á.Z. 2005. Development of a Bio-PIXE Setup at the Debrecen Scanning Proton Microprobe. Nuclear Instruments and Methods in Physics Research, Section B: Beam Interactions with Materials and Atoms, 231: 106-11.

Kovács, K. \& Váczi, G. 2007. The Cemetery of the Early Copper Age Tiszapolgár Culture at Hajdúböszörmény-Ficsori-tódúlő. In: J.K. Kozłowski \& P. Raczky, eds. The Lengyel, Polgár, and Related Cultures in the Middle/Late Neolithic in Central Europe. Kraków \& Budapest: Polish Academy of Arts and Sciences \& Eötvös Loránd University Institute of Archaeological Sciences, pp. 397-409.

Krajcarz, M.T., Krajcarz, M., Sudoł, M. \& Cyrek, K. 2012. From Far or from Near? Sources of Kraków-Częstochowa Banded and Chocolate Silicite Raw Material Used During the Stone Age in Biśnik Cave (Southern Poland). Anthropologie, 50: 411-25.

Kristiansen, K. 2014. Towards a New Paradigm? The Third Science Revolution and its Possible Consequences in Archaeology. Current Swedish Archaeology, 22: 11-71.

Lazarovici, G., Lazarovici, C.-M. \& Constantinescu, B. 2015. New Data and Analyses on Gold Metallurgy During the Romanian Copper Age. In: S. Hansen, P. Raczky, A. Anders \& A. Reingruber, eds. Neolithic and Copper Age Between the Carpathians and the Aegean Sea: Chronologies and Technologies from the 6th to the 4th Millennium BCE. International Workshop Budapest 2012 (Archäologie in Eurasien 31). Bonn: Habelt, pp. 325-52.

Lichter, C. 2001. Untersuchungen $z u$ den Bestattungssitten des südosteuropäischen Neolithikums und Chalkolithikums (Monographien der Heidelberger Akademie der Wissenschaften, Internationale Interakademische Kommission für die Erforschung der Vorgeschichte des Balkans, 5). Mainz am Rhein: Philipp von Zabern.

Luca, S.A. 1999. Sfârtitul eneoliticului pe teritoriul intracarpatic al României - Cultura Bodrogkeresztúr (Bibliotheca Musei Apulensis, 11). Alba Iulia: Muzeul Naţional al Unirii.

Mester, Zs. \& Faragó, N. 2016. Prehistoric Exploitation of Limnosilicites in Northern Hungary: Problems and Perspectives. Archaeologia Polona, 54: 30-50. 
Parkinson, W.A. 2006. The Social Organisation of Early Copper Age Tribes on the Great Hungarian Plain (British Archaeological Reports International Series 1573). Oxford: BAR Publishing.

Parkinson, W.A. \& Gyucha, A. 2007. A késô neolitikum-kora rézkor átmeneti időszakának társadalomszerkezeti változásai az Alföldön. Rekonstrukciós kísérlet. Archaeologiai Értesitó, 132: 37-81.

Parkinson, W.A., Gyucha, A. \& Yerkes, R.W. 2021. Bikeri: Two Copper Age Villages on the Great Hungarian Plain (Monumenta Archaeologica 46). Los Angeles: The Cotsen Institute of Archaeology Press.

Patay, P. 1974. Die hochkupferzeitliche Bodrogkeresztúr-Kultur. Bericht der RömischGermanischen Komission, 55: 3-71.

Patay, P. 2008. A bodrogkeresztúri kultúra belső időrendjéről. Archaeologiai Értesitó, 133: 21-48.

Patay, R. 2002. Settlement Remains of the Bodrogkeresztúr Culture at Mezőzombor. Antaeus, 25: 355-75.

Pop, D., Ionescu, C., Forray, F., Tămaş, C.G. \& Benea, M. 2011. 'Transylvanian Gold' of Hydrothermal Origin: An EMPA Study in an Archaeological Provenancing Perspective. European Journal of Mineralogy, 23: 911-23.

Raczky, P. \& Siklósi, Zs. 2013. Reconsideration of the Copper Age Chronology of the Eastern Carpathian Basin: A Bayesian Approach. Antiquity, 87: 555-73.

Raczky, P., Anders, A. \& Siklósi, Zs. 2014. Trajectories of Continuity and Change between the Late Neolithic and the Copper Age in Eastern Hungary. In: W. Schier \& F. Draşovean, eds. The Neolithic and Eneolithic in Southeast Europe: Nerw Approaches to Dating and Cultural Dynamics in the 6th to 4th Millenium BC (Prähistorische Archäologie in Südosteuropa 28). Rahden: Marie Leidorf, pp. 319-46.

Rajta, I., Borbély-Kiss, I., Mórik, G., Bartha, L., Koltay, E. \& Kiss, Á.Z. 1996. The New ATOMKI Scanning Proton Microprobe. Nuclear Instruments and Methods in Physics Research Section B: Beam Interactions with Materials and Atoms, 109-10: 148-53.

Reimer, P.J., Bard, E., Bayliss, A., Beck, J.W., Blackwell, P.G., Bronk Ramsey, C., et al.
2013. IntCal13 and Marine13 Radiocarbon Age Calibration Curves 0-50,000 Years cal BC. Radiocarbon, 55: 1869-87.

Robb, J. \& Pauketat, T.R. 2013. From Moments to Millennia: Theorizing Scale and Change in Human History. In: J. Robb \& T.R. Pauketat, eds. Big Histories, Human Lives: Tackling Problems of Scale in Archaeology. Santa Fe (NM): School for Advanced Research Press, pp. 3-33.

Roberts, B.W. \& Vander Linden, M. eds. 2011. Investigating Archaeological Cultures. New York: Springer.

Rhyzov, S., Stepanchuk, V. \& Sapozhnikov, I. 2005. Raw Material Provenance in the Palaeolithic of Ukraine: State of Problem, Current Approaches, and First Results. Archeometriai Múbely, 2/4: 17-25.

Shennan, S.J. ed. 1989. Archaeological Approaches to Cultural Identity. London \& New York: Routledge.

Sherratt, A. 1984. Social Evolution in Europe in the Later Neolithic and Copper Age. In: J. Bintliff, ed. European Social Evolution. Bradford: University of Bradford, pp. 123-34.

Siklósi, Zs. 2006. A régészeti kultúra fogalmának változása és az etnikai identitás azonosítása az ősrégészeti kutatásokban. Korall, 24-25: 73-88.

Siklósi, Zs. \& Szilágyi, M. 2016. Módszertani, interpretációs kérdések az alföldi rézkor radiokarbon keltezése kapcsán. Questions on Methodology and Interpretation Concerning the Radiocarbon Dating of the Copper Age on the Great Hungarian Plain. Tisicum, 25: 65-72.

Siklósi, Zs. \& Szilágyi, M. 2019. New Data on the Provenance of Copper Finds from the Early-Middle Copper Age of the Great Hungarian Plain. Archaeological and Antbropological Sciences, 11: 5275-85.

Siklósi, Zs. \& Szilágyi, M. 2021. Culture, Period, or Style? Re-consideration of Early and Middle Copper Age Chronology of the Great Hungarian Plain. Radiocarbon, 63: 585-646. https://doi.org/10.1017/ RDC. 2020.115

Sofaer Derevenski, J. 1997. Age and Gender at the Site of Tiszapolgár-Basatanya, Hungary. Antiquity, 71: 875-89.

Szilágyi, M. 2015. Kora rézkori településszerkezet a Közép-Tisza-vidéken (unpublished $\mathrm{PhD}$ dissertation, Eötvös Loránd University, Budapest). Available 
online [accessed 24 August 2021] at: https://edit.elte.hu/xmlui/handle/10831/ 30002

Szilágyi, M. 2016. Early Copper Age Settlement Patterns in the Middle Tisza Region: Thesis Abstract. Dissertationes Archaeologicae, 4: 395-402.

Szilasi, A.B. 2017. Radiolarite Sources from the Bakony Mountains: New Research. Archaeologia Polona, 55: 243-65.

Uzonyi, I., Rajta, I., Bartha, L., Kiss, Á.Z. \& Nagy, A. 2001. Realization of the Simultaneous Micro-PIXE Analysis of Heavy and Light Elements at a Nuclear Microprobe. Nuclear Instruments and Methods in Physics Research Section B: Beam Interactions with Materials and Atoms, 181: 193-98.

Yerkes, R.W., Gyucha, A. \& Parkinson, W. 2009. A Multiscalar Approach to Modeling the End of the Neolithic on the Great Hungarian Plain Using Calibrated Radiocarbon Dates. Radiocarbon, 51: 1071109.

Zoffmann, Zs.K. 2011. A bodrogkeresztúri kultúra népességének Kárpát-medencei Penrose-kapcsolatai - Embertani lelet Rákóczifalva-Bivaly-tó lelőhelyrôl. Anthropologiai Közlemények, 52: 77-84.

Zoffmann, Zs.K. 2015. Anthropological Data of the Copper Age Cemetery at Rákóczifalva-Bivaly-tó, Bagi föld 1 . Anthropologiai Közlemények, 56: 27-42.

\section{Biographical Notes}

Zsuzsanna Siklósi, a senior lecturer in the Institute of Archaeological Sciences, Eötvös Loránd University in Budapest, specializes in Neolithic and Copper Age archaeology. Her research interests include social archaeology, radiocarbon dating, and archaeological methods and theory. Her current project focuses on the radiocarbon dating of the Copper Age in the Carpathian Basin and the spread of copper metallurgy (NRDI Fund 124260).

Address: Institute of Archaeological Sciences, Eötvös Loránd University,
Múzeum körút 4/B, H-1088 Budapest, Hungary. [email: siklosi.zsuzsanna@btk. elte.hu]. ORCID: https://orcid.org/00000002-6451-5578

Norbert Faragó is a research fellow at the Institute of Archaeological Sciences, Eötvös Loránd University, Budapest. His $\mathrm{PhD}$ on the intra-site analysis of chipped stones from the Late Neolithic site of Polgár-Csőszhalom reflects his research interests in lithic studies, household archaeology, and the archaeological application of GIS and statistics.

Address: Institute of Archaeological Sciences, Eötvös Loránd University, Múzeum körút 4/B, H-1088 Budapest, Hungary. [email: farago.norbert@btk.elte. hu]. ORCID: https://orcid.org/00000002-0351-1223

János Dani, a senior researcher and deputy director of the Déri Museum, specializes in the Central and South-East European Bronze Age. Since completing his PhD on the Early Bronze Age of the Upper Tisza region, he has worked in interdisciplinary fields, such as bioarchaeology, archaeometry, and metallurgy. Recently he has been working within an international interdisciplinary research project 'The Yamnaya Impact on Prehistoric Europe (YMPACT)', funded by the European Research Council.

Address: Déri Museum, Déri tér 1, H4026 Debrecen, Hungary. [email: drdanij@gmail.com]. ORCID: https:// orcid.org/0000-0003-4327-0038

László Csedreki, a senior research fellow at the Institute for Nuclear Research in Debrecen, Hungary, is a specialist in the 
elemental characterization of archaeological metal objects using X-ray spectroscopic methods (XRF, PIXE).

Address: Institute for Nuclear Research (ATOMKI), PO Box 51, H-4001 Debrecen, Hungary. [email: csedreki. laszlo@atomki.hu]. ORCID: https://orcid. org/0000-0001-8169-3360

Zsófia Kertész, a senior research fellow at the Institute for Nuclear Research in Debrecen, Hungary, is an expert in the development of ion beam microanalytical methods and their application in multidisciplinary research. Her other research interest is the physical and chemical characterization of archaeological and related objects by non-destructive analytical techniques.

Address: Institute for Nuclear Research (ATOMKI), PO Box 51, H-4001, Debrecen, Hungary. [email: kertesz. zsofia@atomki.hu]. ORCID: https://orcid. org/0000-0001-9338-395X

Zita Szikszai, a senior research fellow at the Institute for Nuclear Research in Debrecen, is a physicist with a $\mathrm{PhD}$ in experimental medical science, specializing in ion beam analytical methods and their interdisciplinary applications. Head of the Laboratory for Heritage Science, she also manages Hungary's participation in the ERIHS (European Research Infrastructure for Heritage Science) initiative.

Address: Institute for Nuclear Research Research (ATOMKI), PO Box 51, H4001, Debrecen, Hungary. [email: szikszai.zita@atomki.hu] ORCID: https:// orcid.org/0000-0003-1119-3189

Márton Szilágyi is a research fellow at the Institute of Archaeological Sciences, Eötvös Loránd University, Budapest. His research interests include settlement archaeology, social archaeology, and material culture and its relations to past identities. His current project focuses on the temporal and social aspects of pottery use in the fifth millennium $\mathrm{BC}$ in the Upper and Middle Danube region (NRDI Fund 132358).

Address: Institute of Archaeological Sciences, Eötvös Loránd University, Múzeum körút 4/B, H-1088, Budapest, Hungary. [szilagyi.marton84@gmail.com; marton.szilagyi@btk.elte.hu]. ORCID: https://orcid.org/0000-0001-7556-8918

\section{Créer des histoires : différentes perspectives, narrations controversées à Rákóczifalva, site du Chalcolithique ancien sur la Grande Plaine Hongroise}

Un habitat et une nécropole datant du Chalcolithique ont été, entièrement fouillés entre 2005 et 2007 à Rákóczifalva-Bivaly-tó (Site 1/C), ce qui rend possible de comparer l'utilisation de la culture matérielle dans deux contextes archéologiques différents, étand cependant en relation directe et datant de la même époque. Cette situation, rare en archéologie, permet aux auteurs de cet article de mettre en relief des problèmes méthodologiques associés à la distorsion effectuée par les matériels archéologiques provenant uniquement d'habitat ou de nécropole, ainsi que de souligner l'importance de choisir les unités adéquates pour l'analyse. Translation by Madeleine Hummler

Mots-clés: Chalcolithique ancien, Grande Plaine Hongroise, nécropole, habitat, approche basée sur l'analyse de sites 


\section{Geschichten erstellen: Verschiedene Sichtweisen und umstrittene Narrativen aus Rákóczifalva, eine frühkupferzeitliche Stätte auf der ungarischen Tiefebene}

Eine kupferzeitliche Siedlung und zeitgleiches Gräberfeld wurden zwischen 2005 und 2007 in Rákóczifalva-Bivaly-tó (Fundort 1/C) völlig ausgegraben. Diese Ausgrabung ist Anlass für eine Untersuchung der materiellen Kultur, die in eng verbundenen und zeitgleichen, aber verschiedenen archäologischen Kontexten verwendet worden ist. Diese seltene Situation erlaubt den Verfassern methodologische Probleme hinsichtlich archäologischer Fundstätten, wo entweder nur Siedlungsbefunde oder nur Bestattungen vorhanden sind, hervorzuheben. Solch ein Verzerrungseffekt sowie die Bedeutung der Wabl von angemessenen analytischen Einheiten müssen in Betracht gezogen werden, Translation by Madeleine Hummler

Stichworte: frühe Kupferzeit, ungarische Tiefebene, Gräberfeld, Siedlung, ortsbezogene Untersuchungen 